\title{
Smith's paradox of price and negotiation: Empirical evidence from India
}

\author{
Sattwick Dey Biswas ${ }^{1}$ (D)
}

Received: 27 November 2020 / Accepted: 21 July 2021 / Published online: 31 July 2021

(C) The Author(s), under exclusive licence to Springer-Verlag GmbH Germany, part of Springer Nature 2021

\begin{abstract}
Diamond-water paradox has enticed the human mind for generations. Adam Smith gave it a new twist in the Wealth of Nations that serves as the basis of all modern valuation theories. This paper goes back to the original writing of Smith to identify paradoxes and then empirical test in the context of land value. The review of original texts and empirical evidence suggests the existence of a third principle, i.e. "riches and poverty of those who demand". This indication demands a re-evaluation of Smith's paradox of value and has implication of modern science of valuation.
\end{abstract}

Keywords Paradox of price $\cdot$ Negotiation · Valuation $\cdot$ Land acquisition · Compensation

JEL classification Q24 · D46 · P4 · J33

\section{Abbreviations}
LJ (A) Smith, A (1763/1896)
LJ (B) Smith, A (1978/1982

\section{Introduction}

We conduct valuations every day, sometimes to choose between whether to have a coffee or an ice cream, and at other times to decide whether to buy this piece of property or that piece of property (e.g. from everyday groceries to life-saving drugs). Land is one such property that has immense socio-political significance. In the Global South, to expand urbanisation, infrastructure development, and industrialisation, a vast area of land has been transferred from one use to another (Pellissery et al. 2014; Balakrishnan 2019; Pellissery \& Lødemel 2020). As a result, neither the state, nor the market, nor the citizens feel that the processes and outcomes of valuations of land are adequate and

Sattwick Dey Biswas

sattwick.deybiswas@udo.edu

1 Institute of Public Policy, National Law School of India University, Bangalore, India 
just (Alterman 2012; Dey Biswas 2020b, c). In this time of imprecise valuation of land, neither the market (buyers, sellers, and developers), nor the state, nor the citizens have the sense of justice being delivered. The feeling of dissatisfaction and injustice raises the question of legitimacy of valuation methods and in extreme cases triggers violent conflicts (Chakravorty 2013).

The valuation of land has been theorised and experimented with immensely over time in India (Thapar 2002). The modern theories and practice find their roots in Adam Smith's The Wealth of Nations (1776/1981). In this book, Smith borrowed the classic example of the diamond-water paradox to explain his understanding of valuation. He discussed the paradox twice in his writing. While one paradox became the foundation of all modern theories on value (first discussion), the other one went into oblivion (second discussion). This paper investigates, theoretically and empirically, the two discussions on the diamond-water paradox (see below). It deals with the often-ignored second discussion of the paradox which explores how the price of anything, including but not restricted to land, is dictated by the "fortunes of the bidder" (LJ (A), 176-177; LJ (B), 496, 575). Here, the importance of actual negotiation between potential buyers and sellers becomes a source of introspection and questioning of what we think we know about the real-world valuation process.

Because of the need for infrastructure expansion and industrialisation, land acquisition has increased substantially in recent years, globally. The recently acquired land in low- and middle-income countries might be as much as forty-two million hectares (Nolte et al. 2016, vi). Throughout the world, 445 million hectares of land, i.e. an area greater than the size of India, will be acquired to be used for large-scale investments (Deininger et al. 2011). This massive recent acquisition and future prospects have triggered a lot of anxiety and fear among the people who rely on small plots of land for their survival. Their anxiety and exploitation have led to many conflicts in India (Pellissery and Dey Biswas 2012; Chakravorty 2013) and in the Global North-South (Bunkus and Theesfeld, 2019; Borras and Franco, 2012). Often in these cases, the affected population does not receive adequate compensation. Since compensation is linked to the valuation of land, there are differences between the valuation of land conducted by professional valuers and individuals whose lands are expropriated. Therefore, these conflicts can be problematised as our inability to understand how real-world valuation works or how individuals in everyday lives, without professional valuation training to conduct the valuation of land. To understand this real-world problem in the light of Smith's second discussion of the paradox (LJ (A), 176-177; LJ (B), 496, 575), the land acquisition cases at Singur and Salboni, West Bengal, India, are taken as a source of empirical data.

This article is divided into four sections. After Introduction, the second section explores the original two paradoxes discussed by Smith, the third section lays out the empirical evidence, while the last section discusses the conclusion of the paper. 


\title{
2 Smith's diamond-water paradox
}

Modern economics was inaugurated with a riddle (Davy 2012, 90). The riddle is popularly known as the paradox of value, or the diamond-water paradox. Adam Smith (1723-1790) discussed this on two occasions. The popular paradox-even though Smith is discussing this for the second time in his writings, let us consider this as the first discussion-goes as follows:

\begin{abstract}
"What are the rules which men naturally observe in exchanging them either for money or for one another, I shall now proceed to examine. These rules determine what may be called the relative or exchangeable value of goods.

The word VALUE, it is to be observed, has two different meanings, and sometimes expresses the utility of some particular object, and sometimes the power of purchasing other goods which the possession of that object conveys. The one may be called 'value in use;' the other, 'value in exchange'. The things which have the greatest value in use have frequently little or no value in exchange; and, on the contrary, those which have the greatest value in exchange have frequently little or no value in use. Nothing is more useful than water: but it will scarcely purchase anything; barely anything can be had in exchange for it. A diamond, on the contrary, has scarce value in use; but a very great quantity of other goods may frequently be had in exchange for it" (Smith 1776/1981; Book 1, Chapter 4, 44-45; original format).
\end{abstract}

This diamond-water paradox is not something new. The footnote of LJ (A) accepts its ancient roots as far back as Plato's Euthydem (p. 157). The LJ (B) also mentions John Law's Money and Trade Considered (1705) (p. 333). For reasons unknown, the first discussion on the paradox of value has received intense attention, whereas the second discussion has attracted no attention at all. Chronologically, Smith wrote about the paradox as determination of price earlier (LJ (A), 176-177) and then later developed the paradox of value (Smith, 1776/1981, 44-45), but for this paper, I have considered the latter as the first discussion since it is the most popular and widely recognisable one. Interesting enough, we can find the second discussion in the first draft of The Wealth of Nations (LJ (B), 575), but it was later omitted for some unknown reason.

In the second discussion of the paradox of value as the determinant of price, the paradox is used to explain the grounds of preference between two masters of the human species, ${ }^{1}$ i.e. pleasure and pain. Our species requires the necessities of life, but also our delicacy of taste gives us reasons to work for "many insignificant demands". Attributes such as "colour, form, variety or rarity, and imitation"

\footnotetext{
1 Smith discussed a second group of masters of human species, this time a group of individuals or merchants and manufacturers: "All for ourselves and nothing for other people, seems, in every age of the world, to have been the vile maxim of the masters of mankind. As soon, therefore, as they could find a method of consuming the whole value of their rents themselves, they had no disposition to share them with any other persons" (Smith, 1776/1981, 418). The contemporary business community perhaps found that being a master of mankind is not enough; therefore, "Masters of the Universe" is found to be more appropriate (Moore 2009).
} 
constitute grounds of preference (LJ (B), 336 or VI, 13-14). In certain special circumstances, certain goods command high use value but no exchange value. "Cheapness is in fact the same thing with plenty. It is only on account of the plenty of water that it is so cheap as to be got for the lifting, and on account of the scarcity of diamonds (for their real use seems not yet to be discovered) that they are so dear" (LJ (B), 487).

The second discussion deliberates the following determinants of price:

" 1 st, the demand or need for the commodity. There is no demand for a thing of little use; it is not a rational object of desire.

2ndly, the abundance or scarcity of the commodity in proportion to the need of it. If the commodity is scarce, the price is raised, but if the quantity is more than is sufficient to supply the demand, the price falls. Thus it is that diamonds and other precious stones are dear, while iron, which is much more useful, is so many times cheaper, though this depends principally on the last cause, viz: 3 rdly, the riches or poverty of those who demand. When there is not enough produced to serve everybody, the fortune of the bidders is the only regulation of the price." (LJ (A), 176-177; added bold and italics; LJ (B), 496, 575)

The first two principles are well known and much acknowledged when the diamond-water paradox is explained. This is because the first discussion, the most popular one, touches upon these two principles. The existing literature has given relatively less importance to the third principle, if we may call it a principle, discussed in the LJ (A \& B). The popular paradox in The Wealth of Nations goes on to further discuss the "real measure of exchangeable value" and the different parts of which this real price is made up (Smith 1776/1981, Book 1, Chapter 4, 46).

On the one hand, Smith, considered the father of modern economics, is excessively referred to. On the other hand, it is claimed that Smith has been greatly misunderstood (Persky 1989; Sen 2010). Smith has written a lot, so interpretations of the text vary greatly as the readers read different parts of his lengthy works. With "the riches and poverty of those who demand", Smith shows a different interpretation of scarcity. In certain situations, according to Smith, the price of something can break the rules of use value and exchange value. Some thought experiments might produce an alternative conclusion and the situation which we might assume to be an exception can become a market rule. Most rare or scarce objects are owned by richer people (LJ (B), 227-8). An auction is one of the more visible examples of how individuals who can pay higher prices determine the value of the object in question.

(re)Imagine, the thought experiment used by Smith's second discussion on the paradox of value (LJ (A), 177). Smith's thirsty merchant is in the Arabian Desert. The person with a lot of water can intuitively realise the higher value of water to the thirsty merchant. Nevertheless, a merchant travelling the Arabian Desert without a weapon is unreasonable, even in the context of a thought experiment. Therefore, our thirsty merchant can use his weapon to intimidate the person with a lot of water and receive water at little or no expense. This "gun" is nothing but an example of the relative power position between potential buyers and sellers. Similarly, during an imaginary quick conversation between the interested parties, when they are not very altruistic individuals, the person with water might realise the grave need for water 
and demand a high return in exchange for water. The brief conversation in a desert is a representation of a hypothetical negotiation between an interested buyer and seller. In the actual world, such negotiations take place. This empirical investigation is one of many attempts to understand the fruits of such negotiations, but we do this in the light of the paradox of value (LJ (A), 176-177; LJ (B), 496, 575).

Interpreting and reinterpreting Smith has a long tradition. Sen (2010) and earlier Persky (1989) have explained the existing incomplete reading of Smith. As a result, Smith's diamond-water paradox has become as misunderstood as the invisible hand ${ }^{2}$ or division of labour ${ }^{3}$ (van Drimmelen 1987, 66). The strongest possible rejection on the assumption that Smith discussed the paradox of value in the final version of The Wealth of Nations (WN), whereas earlier he has discussed the paradox of price in LJ (A) and LJ (B). Continuing with this, we can see how the final version of the WN paradox of value has shredded the third principle. To the best of my knowledge, no one knows why the final version has omitted the third principle.

By acknowledging this confusion, the paper considers the paradox of value and the paradox of price as we are exploring an exchange, focussing particularly on land. The question is, how do these three principles ultimately explain the value of land during expropriation? Also, to deal with the difference between the paradox of price and paradox of value, we remember von Wieser's objection to Smith's theory of value (1889/1893, xxvii). Von Wieser claimed Smith has proposed two theories of value. One of them is the philosophical definition of value. The philosophical definition of value is determined by the amount of labour involved in producing commodities. Smith's empirical theory of value, or observable real-life transactions, interests, capital requirements, and rent, constitutes the value. This paper takes comfort in knowing that Smith saw that value could be represented through price (LJ(A), 182-190). With that, this paper will explore how individuals define and differentiate between value and price. We will also explore the scope and limits of equating monetary price with the value of land.

With this background, this paper has taken two land expropriation case study

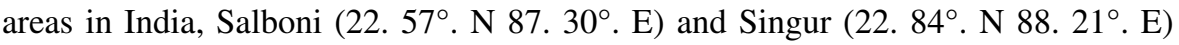
within the state of West Bengal, as a source of empirical data. These two cases have produced opposite outcomes, even when the same Land Acquisition Act 1894 was enforced. We know the infamous Singur case due to the people's movement that was

\footnotetext{
2 Smith has discussed the invisible hand twice and neither of these discussions indicate what traditional social science attributes to Smith (1759/1853: 264-265; Smith, 1776/1981: 445-456).

3 Smith's understanding of the consequences of the division of labour also includes this:

"In the progress of the division of labour, the employment of the far greater part of those who live by labour, that is, of the great body of the people, comes to be confined to a few very simple operations; frequently to one or two. But the understandings of the greater part of men are necessarily formed by their ordinary employments. The man whose whole life is spent in performing a few simple operations, of which the effects, too, are perhaps always the same, or very nearly the same, has no occasion to exert his understanding, or to exercise his invention, in finding out expedients for removing difficulties which never occur. He naturally loses, therefore, the habit of such exertion, and generally becomes as stupid and ignorant as it is possible for a human creature to become. ... the great body of the people, must necessarily fall, unless government takes some pains to prevent it" (Smith 1776/1981, 506: bold and italics added).
} 
Table 1 Composition of participants: individual interviews

\begin{tabular}{llrcc}
\hline Sl. no & Category & Male & Female & Total \\
\hline 1 & Sample size & 30 & 30 & 60 \\
2 & Salboni & 15 & 15 & 30 \\
3 & Singur & 15 & 15 & 30 \\
4 & SC (Scheduled Caste) & 10 & 10 & 20 \\
5 & ST (Scheduled Tribe) & 4 & 4 & 8 \\
6 & Subject to expropriation & 15 & 15 & 30 \\
7 & Stakeholders & 15 & 15 & 30 \\
8 & Representatives of industry & 3 & 2 & 5 \\
9 & Political representatives & 5 & 5 & 10 \\
10 & Public servants & 5 & 5 & 10 \\
11 & Civil society & 2 & 3 & 5 \\
\hline
\end{tabular}

heavily supported by opposition political parties, the police brutality and the termination of TATA's dream project to build the world's cheapest car (details of Singur case in Nielsen 2018). The second case of land acquisition at Salboni represents a much-celebrated land acquisition at the state and local level. The company, JSW, for which the state acquired the land, provided a much more generous compensation package along with state-provided compensation. These two cases, albeit located in a similar sociocultural atmosphere, have produced completely different post land acquisition outcomes. With Singur, the land acquisition involved a vast area of agricultural land (Nielsen 2018), whereas, in the case of Salboni, only a small proportion was single cropping agricultural land, while the rest comprised not-much-used fodder farm areas (Mathur 2013). This selection of cases ensures the exclusion of all other factors and thus enables the study of the "valuation" problem (Flyvbjerg 2006).

The collection of data took place over eight months, between November 2016 and June 2017, involving typical on-site residence for a better ethnographic understanding of the cases. The data comprise 60 qualitative interviews, each lasting between 60 and 120 min, six Focus Group Discussions (FGD), and the study of maps and photographs (see Table 1). The transcript data run to over 1200 pages. I conducted a thematic analysis of the transcribed data to explore the social realities of life (Mason 2002).

During the investigation, I employed a series of well-thought-out questions to elicit responses, which could be later be categorised under different emerging themes such as valuation, negotiation etc. While eliciting responses, I was sensitive to Descartes' recognition of what we may call "the creative aspect of language use" to understand the everyday use of language. My attempt to understand social realities via interviews was restricted by the ordinary use of language, which is typically innovative without restrictions (Chomsky 1982). Responses to questions came appropriate to circumstances but not necessarily caused by questions (D'Agostino $1984,91)$. As an interviewer I tried to ask questions in various ways, often paraphrasing the same questions in different ways and while introducing different real 
and hypothetical circumstances. The questions asked were not always "what did the respondent do during a negotiation or how did his/her last negotiation go", but in many cases "how does a negotiation usually go". The responses often came as "suppose one wants to sell his land," instead of "when I wanted to sell my land". We may consider such third person based answers as a figure of speech, commonly used in rural West Bengal, India. The hypothetical question is more appropriate in the context of negotiation because we are interested in knowing what goes on within the process but not necessarily in the respondent's life.

The objective was to encourage the respondents to reflect upon their responses and ground them to social realities as much as possible. Considering the cultural context and sensitive nature of case study areas (land acquisition-related conflicts) and to maintain confidentiality, the participants were often asked to imagine hypothetical situations, like land ownership, land deals, land acquisition processes, and incorporate their life experience in those hypothetical situations. This technique established a safe atmosphere where the participants were comfortable to describe and discuss controversial and often shrewd techniques used during negotiation. ${ }^{4}$ Therefore, the respondents answered while reflecting on their own experience and also by incorporating the experience of others which they had heard throughout their lifetime.

The answers were followed up with "why" and "how" questions to ensure such answers did not become imaginative but were grounded in reality. Where respondents were found to be exaggerating too much, either the respondents were specifically informed about the interviewer's long empirical experience on the land issues of the region or they were given an indirect indication that such answers are difficult to believe. Answers which contradicted the established literature were collaborated with multiple respondents. The answers may sound as if all respondents are landowners but participants and quoted texts represent the composition of the sample.

\section{Empirical evidence}

I present the empirical evidence under two broad thematic schemes. The first part discusses the nature and the role of negotiation in determining the value during any exchange. The second part presents evidence related to the paradox of value (LJ (A), 176-177; LJ (B), 496, 575).

\footnotetext{
4 The scope and limits of hypothetical questions and their use for different contexts can be explored in Herskovits (1950) or Speer (2012). For the use of hypothetical situation in hypothetical stimulusresponse research, see Mikhail (2011).
} 


\section{Negotiation}

From the minor issues (like what should we cook for tonight's dinner) to bigger things that involve states and international politics (UN, EU, ASEAN to name a few), negotiation is the process by which human society agrees, disagrees, and acts. The question of interest here is; are real-world negotiations different from what the dominant literature tells us. The participants in this empirical investigation have indicated that the seller proposes (predominantly) the monetary price or any other mode of pricing (where apartment blocks or market places will be built) of the land. That "the seller proposes the price or means of exchange" is not universally accepted. The practice of the buyer proposing the monetary price or exchange amount is not rare. Mr. Saiket, a resident of Singur (on 1 April 2017), expressed his experience as follows:

"As a buyer, I can propose 5 INR and even 500,000 INR. Suppose if I have taken one thing to the market and someone asks me about the rate, what do I say about the price? It is you who are buying the thing, you should propose a rate. This is how the market works; you are the one who will propose a rate."

During the interview, the participants of the study agreed that both the buyers and the sellers propose the monetary price (or other means) and they negotiate. Ms. Debolina, a resident of Singur (on 4 April 2017), described the nature of negotiation:

"As a seller, no one can move from a lower position to a higher position. You have to start at a higher price so that it does not go down that much. If you can start at a higher price, then it can come down 50-60,000 INR. As a buyer, if I have proposed 80,000 INR and leave the negotiation for the moment, then the owner of the land will go to the market area and enquire if anyone is interested to pay over 80,000 INR."

This understanding of the bargaining process has some merits. Leaving Vito Corleone on the one side and Gandhi on the other side of the spectrum, it is hardly possible in an ordinary circumstance to move from a lower exchange demand to a higher demand if one is selling his or her goods or services. It is possible only when the seller is at a higher socio-economic-political position and playing with the desperation of the relatively eager buyer. The owner of the land continues to look for someone who will bid a higher price.

During the exploration for an alternative bidder, both the buyer and the seller attempt to anticipate how much higher or lower the other person is willing to go. If the seller can anticipate the buyer's immediate need for the land and there is no alternative land available with similar characteristics then the seller asks for a higher price with or without giving an example of a hypothetical/dummy buyer who is ready to pay more. If the potential buyer can forestall a seller's weak position/ or desperation, then the potential buyer might use this intuition (or information) to exchange the land for much less. Ms. Debolina, a resident of Singur, has described the relative position of the buyer and seller. If there is an urgency from the buyer's or seller's end, and the other parties are aware, then the other party tends to 
exploit such a situation. As a result, we exchange a usually valuable thing at a lower exchange value. There is a disconnect between the monetary price or exchange package (including but not restricted to the annuity, pension, health insurance, scholarships, job/vocational training and development rights) for which the land is usually exchanged.

From the seller's perspective, the success of exchanging with a high return hinges on how many prospective buyers can be reached within an acceptable period and how to advertise his/her intention to exchange. During this empirical investigation, we learned that there can be many reasons behind the lack of interest in selling land. The reasons can be broadly categorised under, (a) absence of dire need, (b) apprehension that the future value of the land will be higher, or the hold-out problem, (c) the sentimental value of land, i.e. no matter what, the land should remain with the owner's family, and (d) not having any other form of livelihood. In these situations, sometimes no higher price can convince the seller to sell land.

The participants of the expropriation case also suggest that the seller will only agree to expropriation or exchange when his or her descendants have received a secure livelihood. Also, an extraordinarily high monetary price for land might persuade the seller to exchange the land. The participants of the study indicated that the negotiating owner has every interest to know from which place the buyer is coming from, religion and caste, and what will be the future use of land. Ms. Antara, a resident of Singur (on 1 April 2017), described how this information feeds into the valuation procedure.

"What you are going to do with the land, I want to know. That can be a factory, or industry or just farming. After knowing this I am going to answer this question...Someone might ask me that they want a little bit more land so they are talking with three-four people, it will be good if they will be given the land. People will fix the monetary price higher according to it (future use)."

The participants of the study were explicit on the issue of consent. Ideally, no transaction should take place without the full consent of the potential buyer and seller. The participants of the study, who were subject to expropriation, or stakeholders, took the issue of consent very seriously. Especially during the expropriation where the state is the "buyer", due process, consultations and consent are expected to be fulfilled consistent with the laws of the land. Also, since the state has an obligation towards its people and hence the future owner of the land, financial and nonfinancial compensation can be explored. It is also because the state is mighty, ruler and master of its people, therefore by providing a higher valuation for land, the state loses nothing but only gains the goodwill of the people and improved quality of life. The expectation of participants of the study regarding the importance of consent reflects the many forced land acquisitions or land grabs of our time (Pellissery and Dey Biswas 2012; Chakravorty 2013; Bunkus and Theesfeld 2019).

Therefore, consent might be easy to get if the exchange benefits are higher or make life better than it is now. What makes life better is not necessarily monetary or financial terms (such as stock, bond, fixed deposits) but includes non-financial compensation. Non-financial compensation includes stability in life, assurance over a protected future, respect, trust, social recognition, and a viable path towards an 
improved quality of life. In the case of such a transaction, irrespective of where it is discussed, whether an informal social gathering of Dortmund real-estate investors or participants of the study in Salboni and Singur, the most attractive characteristic of the land is its fertility, therefore, it commands a high value. During expropriation of land, we should mostly avoid such highly fertile land. We documented similar data in the past, and the issue was more or less problematised as agriculture land use vs other land use, or the sentimental value of the land to the farmers vs industrial use. This earlier problematisation establishes other social realities of time and space, the often-furious resistance to the acquisition of multi-crop land can be also problematised as the issue of consent or absence of it.

During any potential deal, the brokers play significant roles. Ms. Antara, a resident of the Singur area (on 1 April 2017), indicated the roles played by the brokers:

"There are brokers...There is a group of people who buy and sell the land and because of these get some commission... Perhaps someone has arranged 2 bighas of land for you, you will buy, and another guy will sell. What I will do is, I will say...there is a piece of land available there, will you buy it? He will say this amount...I must pay some commission to him."

The participants claimed that infrequently the land deal broker can extract profits for little intervention without the knowledge of the final buyers and original sellers. Sometimes, many "in-between" transactions may take place without immediate knowledge of prospective final buyers or sellers. The same happened before in Salboni and Singur and often happens before the announcement of a large project (public/private). The land deal brokers and interested rich individuals have access to land acquisition-related, privileged insider information. By using this information, they buy vast areas of land in and around the project area. They quickly resell the land to large projects and earn a higher monetary price or returns of the land.

The big "other" in these negotiations between potential buyers and sellers is the state and other statutory bodies. The spread of misinformation makes negotiation very complicated. In the context of expropriation of land, especially in the Singur anti-land acquisition movement, propaganda and counter-propaganda were at play. Interested parties, whether supporting land acquisition or against it, planted false, incomplete, and misguided rumours. The misinformation complicates the negotiation further when ROR (Record of Rights) and cadastre maps, on which basis the valuation of land and compensation have to be determined, are found to be incomplete and outdated. One of the participants of the study, Mr. Abir, a resident of the Salboni area, described how with non-updated maps, land transactions somehow continue to take place when a private transaction takes place. The land rights formalisation in India has improved over time, but still a lot of loopholes needed to be fixed (Dey Biswas 2014; Appu 1996).

The influential grassroots members of political parties and bruisers use every opportunity to use lawful, extra-legal, and unlawful tricks to enforce their will to suppress any dissent against possible land transactions. Political factions make sure that such enforcement remains unchallenged. Often, organised political parties are heavily involved with land issues (Barraclough 1999). At Singur and in the state of West Bengal, those who oppose enforced expropriation of land often employ 
dominant political rhetoric: "land is soil, the soil is mother, and we don't sell our mother".

This empirical research shows evidence of roles played by various actors such as (potential) sellers, buyers, brokers, powerful "other" stakeholders and others during the land valuation and transaction processes. This does not show an ideal "zero" transaction cost scenario by Coase (Coase 1960; Bronk 2013; Dey Biswas 2020a). The cost of using the market appears to be high for the parties in negotiation and potential transaction. During the negotiations, the potential buyers and sellers try to anticipate each other's weak positions, or desperation, to make the deal beneficial for themselves and potentially less rewarding for the other party. The success of the seller depends on finding someone willing to be the highest bidder. A potential seller will continue to hold out if he/she can anticipate a substantial increase in the future price of land and the need of the present can be mitigated via other sources of income or provisions. The evidence suggests that the ideal valuation procedure is far from social reality in the absence of "proper marketing wherein the parties have each acted knowledgeably, prudently and without compulsion" (TEGoVA 2016, 17) in valuation.

\section{The paradox of price}

During the data collection, I attempted to linguistically differentiate the words "value" and "price" in the vernacular local language (in Bengali). Different words such as "dam" (meaning value, worth, price and cost), "mulya" and "gurutoya" (something not restricted to money or "dam") were used when interviewing the participants of the study. This exercise was linguistically challenging as it quickly identified participants' tendency to mix value and price in their answers. Therefore, forceful interjections were made to emphasise our intention to understand the monetary price but also go beyond monetary price. This challenge of differentiating between the value of land and the monetary price of land is not restricted to the Bengali language (spoken by about 230 million people in the world) but arises in other languages too. Whether it is the emergence or the dominance of the market economy or something else that has contributed to establishing this confusion is yet to be fully understood (see Appendix 1 to understand the confusion over value and price). There is some evidence to suggest that people often use the same word to describe something else. ${ }^{5}$

The participants of the study usually began with their understanding of value. The demand (for the land or anything else) and the supply of the land are constantly interacting with each other to generate the value of land as well as value in terms

\footnotetext{
5 In a non-valuation context, one such interesting example is the use of the words, "fly" and "jump." We accept that chickens are capable of "flying", Olympian Carl Lewis' could only "jump" (8. $91 \mathrm{~m}$ or $29 \mathrm{ft}$ 2. 7 inches). If there are hypothetical competitions, then in most cases, Carl Lewis will probably jump further than a chicken's ordinary flight (for Carl Lewis' jump, please see https://www.iaaf.org/athletes/ united-states/carl-lewis-1622).
} 
of monetary price. Rarely, participants of the study expressed that the value of land does not simply follow demand-supply equilibrium. They could not explain why the value of land does not follow basic economic understanding.

Against the Ricardian fear of high land prices destabilising a society (Piketty 2014, 14, 15), Mr. Sujan, a resident of the Salboni area (on 2 April 2017), had a feeling - as did several others - that in the near future, the value of land would only rise. The underlying reasons are (a) devaluation of money, and (b) an increase in price of other goods and services (Rothbard 2002, 328). Investment decisions influence value and value as the monetary price of land, the social-culture-economic (in) stability at the time, location, surrounding land use, and preferences in society on many related things. Ms. Debolina, a resident of Singur (on 4 April 2017), explained the social question in the valuation of land:

"No, not like that. If I say that rice imports will go up depending on demandsupply, the price of the land does not depend on these things. Then, it depends on what? It depends on the economic situation. Suppose we have laboured at my house. I have unemployed sons in my house, now I have to find some work for them to get them employed. Now I will employ my sons on the land, and my earnings will be better. This is the reason why some people buy land. Nowadays, why are people buying land? Because there are lots of problems with money. The situation has become such that if I keep money in the bank, then I need to pay the bank instead of receiving interest. There are charges to be paid if you are buying a piece of land or selling a piece of land. This is the reason people are accumulating land to save money, expecting the price of land goes up! Not for other reasons but depending on the economic situation many people buy land."

Ms. Debolina specifically asked us to reconsider the socio-economic circumstances and different choices individuals make to safeguard the present and future demands of life via land or any other means. These factors influence the owner of the land if the demand-supply equilibrium is challenged for each individual's case. The location-specific increased demand for land increases the value of land and value in terms of the monetary price. Leading land valuation authorities see merits in such analogies (e.g. Lincoln Institute 2016).

The socio-economic and cultural situation of the time influences the use and exchange value of land. The economic and social security conditions of the individuals (sellers or buyers) or communities, such as in the middle of the COVID19 pandemic, have a significant effect on the price of land. In such a situation, the productive capacity of land may not have been influenced at all. For example, an orchard will continue to bloom before and after COVID-19, but the context changes if the fruits of the land or the benefit derived on the land or from the land, including but not restricted to crops and business opportunities, can be utilised or not.

The participants of the study agreed that land is more valuable than gold and any other commodity. Land can be monetised at any time to meet the social security needs of the time or to mitigate social risks (such as unemployment, pandemic, 
natural disaster, etc.). Money is a naughty virus, i.e. there are always many ways to spend an enormous amount of money. The arrival of money in a community triggers a spending extravaganza in a family, and the family struggles to meet the demands of family members and the newly wealthy society (Levien 2018). These understandings also deter many communities from preferring land itself to the monetary value of the land.

\section{The third principle}

We learned that in the real world the third principle passively and actively works to determine value and value determined in terms of price. Ms. Madhumita, a resident of Singur (on 12 April 2017), discusses the third principle:

"The price of the land? It will depend on me and you. Whoever has more money will determine the value of land. If I have a genuine interest, I might propose 5,000 INR. Another person might increase it further. Whoever has more money will determine the price. This is how the price is determined."

A potential seller searches for and contacts the highest possible bidder. A negotiation begins within which an anticipation game concludes who can correctly gauge the other's limitations. The result produces a higher potential value, and value in terms of monetary price. The key is to anticipate the eagerness to buy or sell and to correctly anticipate the relative wealth of the buyers and sellers. Mr. Shymal, a resident of Salboni (on 2 February 2017), describes this process as the "the natural order" and like von Wieser $(1889 / 1893,16,18)$ is concerned about the future use of land:

"Individually means? You mean that I have a need and I am selling my land. In that case, if the other person is not an industrialist. Then how can I demand a job? In case, where an industrialist is buying a piece of land, then I will ask something bigger... Of course, that you can claim. Because, when I need money, I might sell my land to him. When the government is taking, I am demanding this or that thing. Depending on the capacity (of the buyer) we are asking. This (is what) you can say. This is the natural order."

A higher price-based valuation of the land often tempts the unwilling seller to sell. Ms. Aanamika, a resident of Salboni (on 13 April 2017), explained: "In exchange for land what else can I ask? Perhaps I will ask for a higher price for the land than the usual rate." The opposite sentiments are not the minority, i.e. there are individuals for whom, if not compelled to sell, any higher valuation-based compensation is not persuasive enough.

Individuals, in their mundane daily life, try to balance instant financial rewards in exchange for land and long-term implications for the relationship with the potential seller. In the community, it is often goodwill or muscle power that encourages 
or discourages a transaction. Even when an outsider is willing to provide a higher valuation of land, the local schoolteacher, Panchayat member or distant relative who is willing to give a lower valuation will be given the land. The owner of the land receives goodwill which is more valuable in a community than the higher material valuation of land. The hypothetical future influences, recognition, social and political partnership and potential future favours dominate the valuation of land more than the immediate higher valuation of land.

\section{Value as price}

Everyday struggles to differentiate between value and value presented in terms of monetary price are quite remarkable (see Appendix 1). The participants of the study struggled to distinguish the concept of the value and the monetary price. The conceptual and everyday confusion has left its mark in many major languages of our time. When asked about land values, the participants answered in terms of monetary price. Sometimes they also used monetary return from the land. The former has linguistic implications, and the latter is now embedded in the real-estate valuation methods (the income approach or investment method, see Shapiro et al. 2012, 12-15). Mr. Prabhat, a resident of Singur, gave the most direct answer (on 25 April 2017): "The meaning of value is the monetary price."

Over time, the devaluation of money in one's life becomes the only reason some participants do not consider that the value can be presented in terms of monetary price. To them, monetary price is not the right way to look at the value of land. Ms. Antara, a resident of the Singur area, described her experience with monetary price and devaluation of money over time. The limitations are quite compelling (see also Sandel 2012). Ms. Rahaman, a resident of the Singur area (on 22 May 2017), discussed the incompleteness in equating monetary price to value.

"Usually, when they decide the value of land, they do it as if it is farmland... before land is transformed for another use. You are not deciding the value by keeping in mind the fact that there will be TATA's factory or other factories. This means, the farmers are giving everything, but in exchange, they pay you only the monetary price equal to the farmland. Did you think about this? Like I said to you before, with monetary units of measurement, you cannot value land."

In these situations, other ways to exchange things should be explored. Money is a medium of exchange. It is not the absolute one, but a medium of exchange among many alternatives. 


\section{Conclusion}

This paper explored the less discussed paradox of price from an empirical point of view. It especially looked for signs of Smith's third principle: the "riches and poverty of those who demand." For reasons unknown, this third principle was later omitted in the WN final draft but present in the Lectures (LJ (A), 176-177; LJ (B), 496, 575). The empirical evidence presented in this paper encourages us to look beyond the established reading and interpretation of the paradox of price.

The participants of the study spontaneously indicated the importance of demand and supply of land. It is the function of these two that regulates the value of land and the value represented in terms of the monetary price of land. Another important factor that came out spontaneously is how demand and supply at a specific "location" matter more. These spontaneous answers are in line with the established valuation methodology promoted by leading bodies such as the Lincoln Institute (2016).

The future employment prospect (for the seller) in any context influences an individual's understanding of the value of land. Given the various future uncertainties of life, lack of livelihood opportunities, and absence of formal social security mechanisms available to most of the participants of the study, they considered land a more attractive option than gold. Land is a more reliable source of sustenance via agricultural production and food security. In the absence of the culture of money and the devaluation of money over time, land is more valuable than the alternatives.

The empirical investigation documents some evidence to support the existence of a third principle (LJ (A), 176-177; LJ (B), 496, 575). According to the participants of the study, the fortunes of the bidders, or the wealth of the bidder, or the interested party's capacity to pay will determine the price of land. In this context, the participants of the study emphasised that negotiation plays an important role, where an intuition game is played to gauge how high or low, in terms of valuation, the other party can go.

The everyday confusion over equating value and monetary price is quite dominant. The empirical investigation found that the participants quickly and spontaneously equated the value and the price. Limited research in other languages also indicated widespread confusion. Whether the conventional wisdom of equating these two has changed the language, or vice versa, is yet to be fully understood.

\section{Appendix 1}

See Table 2. 


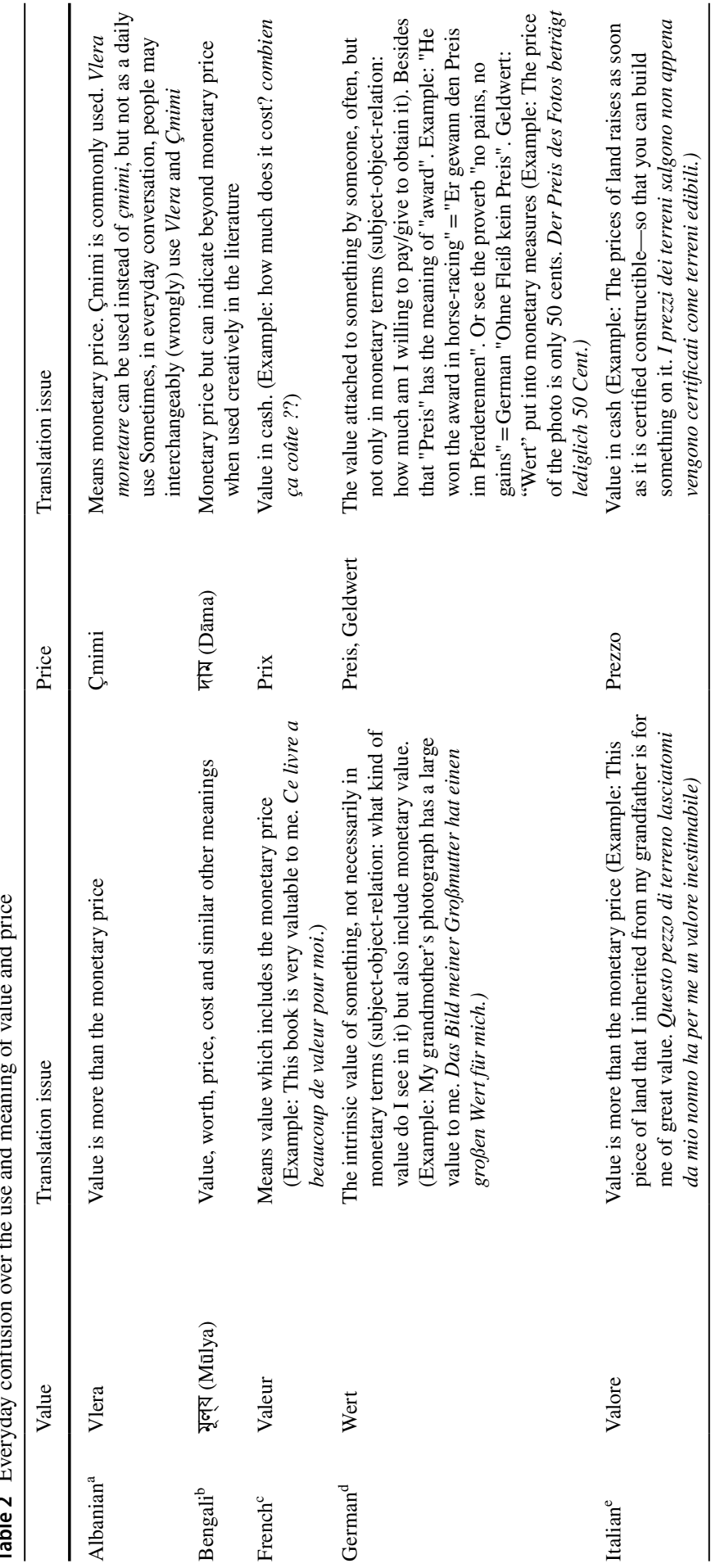




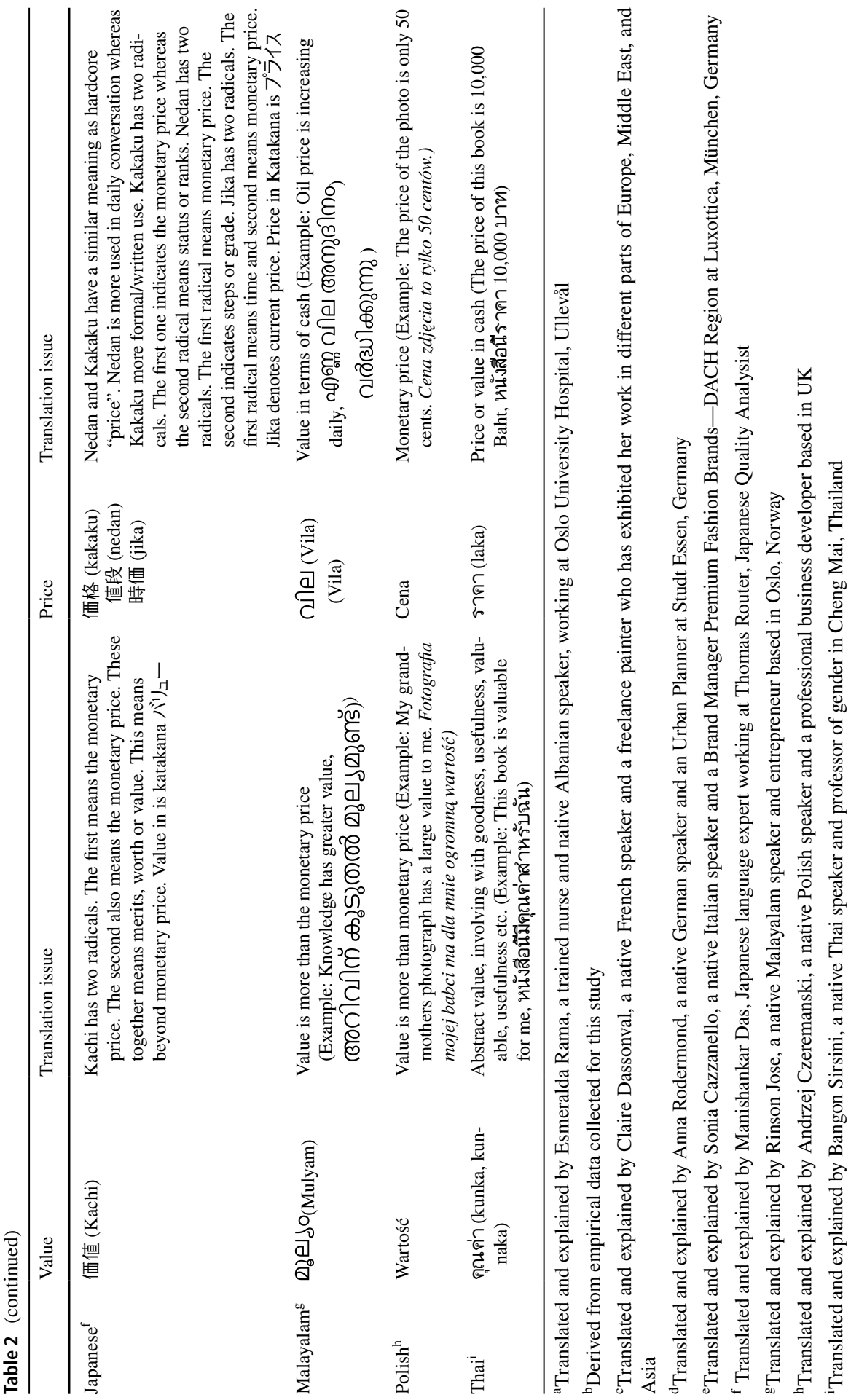


Acknowledgements I want to thank the anonymous reviewers and the editor for their constructive feedback. Also, I want to acknowledge fruitful discussions on the core themes of the article with Benjamin Davy, and Thomas Hartmann, along with Atreyee Sen, Daniel Bromley, Franziska Seilker, Ivar Lødemel, Kenneth Bo Nielsen, M. Mercedes Stickler, Michael Kolocek, Paramita Roy, Rachelle Alterman, Roshan Thomas, Sattwati De Biswas, Sony Pellissery, Sudipa Sarkar, Yoram Barzel, and Yitu Yang. I am grateful to Esmeralda Rama, Claire Dassonval, Anna Rodermond, Sonia Cazzanello, Manishankar Das, Rinson Jose, Andrzej Czeremanski, and Bangon Sirsini for the very crucial translation work. I am thankful to the participants of International Academic Association on Planning Law and Property Rights Annual conference 2017, South Asia across the Nordic Region Conference 2018, and Young Scholar Initiative Plenary, Institute of New Economic Thinking, 2020 (WG History of Economic Thought) for their thoughtful questions and engagements with the topic. Jan Russell (jan@kabarmedia.com) has kindly copy-edited this article. All remaining errors are mine.

Funding This research did not receive any specific grant from funding agencies in the public, commercial, or not-for-profit sectors. I would like to thank School of Spatial Planning, TU Dortmund University and Institute of Public Policy, National Law School of India University for providing generous working space and intellectual support.

Data availability There are no data provided with this paper. The empirical data were collected during the author's doctoral study at the School of Spatial Planning, TU Dortmund University. The reliability and confidentiality of the data were vetted by the doctoral committee and the concerned department at the university. Due to the sensitivity of the research topic and the nature of the agreement between the researcher and the participants of the study, the raw data cannot be shared with any third party. The coding rules for thematic analysis of the qualitative empirical data was party published by the author in "Land acquisition and compensation in India: Mysteries of valuation" (2020) with Palgrave Macmillan.

\section{Declarations}

Conflict of interest As per the author's knowledge and awareness, there is no potential conflict of interest.

Ethical approval As a part of doctoral research, the data collection for this research was approved by the relevant authorities at the School of Spatial Planning, TU Dortmund University, Germany. Confidentiality agreements were signed with the participants of the study. The interviews and the group discussions were audio-record, transcribed and impersonalised. The pseudonames (imaginary first names) were used when quoting a particular respondent or group of respondents to maintain anonymity and confidentiality.

\section{References}

Alterman R (2012) Land-use regulations and property values: the "Windfalls Capture" idea revisited. In: Brooks Nancy, Donanghy Kieran, Knapp Gerrit-Jan (eds) The Oxford Handbook on Urban Economics and Planning. Oxford University Press

Appu PS (1996) Land Reforms in India: A Survey of Policy, Legislation and Implementation. Vikas Publishing House, New Delhi

Balakrishnan S (2019) Shareholder Cities: Land Transformations along Urban Corridors in India. University of Pennsylvania Press, Philadelphia, PA

Barraclough SL (1999) Land reform in developing countries: the role of state and other actors. Geneva: UNRISD Discussion paper No. 101. Retrieved from http://www.unrisd.org/80256B3C005BCCF9/\%28htt pAuxPages\%29/9B503BAF4856E96980256B66003E0622/\$file/dp101.pdf. [accessed 29.08.2019].

Borras S, Franco J (2012) Global land grabbing and trajectories of agrarian change: a preliminary analysis. J Agrar Chang 12(1):34-59

Bronk R (2013) Hayek on the wisdom of prices: a reassessment. Erasmus J Philos Econ 61(1):82-107. https://doi.org/10.23941/ejpe.v6i1.120 
Bunkus R, Theesfeld I (2019) Land grabbing in Europe? socio-cultural externalities of large-scale land acquisitions in east Germany. Land 2018(73):98. https://doi.org/10.3390/land7030098

Chakravorty S (2013) The Price of Land: Acquisition, Conflict, Consequence. Oxford University Press, New Delhi/Oxford

Chomsky N (1982) A note on the creative aspect of language use. The Philosophical Review 91:423. https://doi.org/10.2307/2184692

Coase RH (1960) The Problem of Social Cost. J Law Econ, 3:1-44. Retrieved from http://www.jstor.org/ stable/724810. Accessed 4 Sept 2018.

D’Agostino F (1984) Chomsky on creativity. Synthese 58:85-117. https://doi.org/10.1007/BF00485363

Davy B (2012) Land Policy: Planning and the Spatial Consequences of Property. Ashgate, Farnham

Deininger K, Byerlee D (2011) Rising Global Interest in Farmland. The World Bank

Dey Biswas S (2014) Land rights formalization in India: Examining de soto through Rawls theory of justice: Working Paper. FLOOR (Financial Assistance (Social Cash Transfers), Land Policy, and Global Social Rights). http://www.floorgroup.raumplanung.tu-dortmund.de/FLOOR_Working_ papers/FLOOR_WP018_Dey_Biswas_Land_rights_formalization_India.pdf. Accessed 4 Sept 2018

Dey Biswas S (2020a) Land acquisition and compensation in India: Mysteries of valuation. Palgrave Macmillan, NY. https://doi.org/10.1007/978-3-030-29481-6

Dey Biswas S (2020b) Social citizenship and plural values of land: land acquisition cases from India. Soc Policy Soc 19(2):331-342. https://doi.org/10.1017/S1474746419000496

Dey Biswas S (2020c) Plural values of land: an empirical investigation. J Land Rural Studies 9(1):140157. https://doi.org/10.1177/2321024920968333

van Drimmelen R (1987) Homo Oikumenicus and Homo Economicus. Trans: Int J Holisti Miss Stud 4(3-4):66-84. https://doi.org/10.1177/026537888700400415

Flyvbjerg B (2006) Five misunderstandings about case-study research. Qual Inq 12(2):219-245

Herskovits M (1950) The Hypothetical Situation: A Technique of Field Research. Southwest J Anthropol, 6(1), 32-40. Retrieved June 28, 2021, from http://www.jstor.org/stable/3628688

Lincoln Institute (2016) Land and Property Values in the U.S. Tech. rep., Lincoln Institute of Land Policy. URL: http://datatoolkits.lincolninst.edu/subcenters/land-values/ [accessed 29.08.2019].

Levien M (2018) Dispossession Without Development: Land Grabs in Neoliberal India. Oxford University Press, NY

Mason J (2002) Qualitative Researching. SAGE, London

Mathur HM (2013) Displacement and Resettlement in India: The Human Cost of Development of Routledge contemporary South Asia series. Routledge, London

Mikhail J (2011) Elements of Moral Cognition: Rawls' Linguistic Analogy and the Cognitive Science of Moral and Legal Judgment. Cambridge University Press, Cambridge

Moore S (2009) Masters of the universe. Financial Times. Accessed at: https://www.ft.com/content/ 68d6ad0a-da21-11de-b2d5-00144feabdc0 [accessed 29.08.2019].

Nielsen KB (2018) Land Dispossession and Everyday Politics in Rural Eastern India. Anthem Press

Nolte K Chamberlain W Giger M (2016) International Land Deals for Agriculture. Fresh insights from the Land Matrix: Analytical Report II. Bern, Montpellier, Hamburg, Pretoria: Centre for Development and Environment, University of Bern; Centre de coopération internationale en recherche agronomique pour le développement; German Institute of Global and Area Studies; University of Pretoria; Bern Open Publishing. Retrieved from https://landmatrix.org/stay-informed/internationalland-deals-agriculture-fresh-insights-land-matrix-analytical-report-ii/ [accessed 29.08.2019].

Pellissery S, Dey Biswas S (2012) Emerging property regimes in India: what it holds for the future of socio-economic rights? SSRN Electron J. https://doi.org/10.2139/ssrn.2179717

Pellissery S, Lødemel I (2020) Property and social citizenship: social policy beyond the north. Soc Policy Soc 192:275-292

Pellissery S, Davy B, Jacobs J (eds) (2014) Land Policies in India. Springer, Singapore

Persky J (1989) Retrospectives: “Adam Smith's Invisible Hands”. J Econ Perspect 3:195-201

Piketty T (2014) Capital in the Twenty-First Century. Harvard University Press

Rothbard MN (2002) A history of money and banking in the United States: the colonial Era to World War II. Ludwig Von Mises Institute, Auburn

Sandel MJ (2012) What Money Can't Buy: The Moral Limits of Markets. Farrar, Straus and Giroux

Sen A (2010) Adam smith and the contemporary world. Erasmus J Philos Econ 3:50-67. https://doi.org/ 10.23941/ejpe.v3i1.39

Shapiro E, Mackmin D, Davies K (2012) Modern Methods of Valuation. Estates Gazette

Smith A (1759/1984) The theory of moral sentiments. In: Raphael AL (ed) Liberty Fund, Indianapolis 
Smith A (1763/1896) Lectures on Justice, Police, Revenue and Arms, delivered in the University of Glasgow: Reported by a Student in 1763 and edited with an introduction and notes, by Edwin Cannan, Oxford: Clarendon Press, http://oll.libertyfund.org/titles/2621 [accessed 29.08.2019].

Smith A (1776/1981) An Inquiry into the Nature and Causes of the Wealth of Nations. Indianapolis: LibertyClassics.

Smith A (1978) Lectures on Jurisprudence. In: Meek RL, Raphael DD, Stein PG (eds) This volume includes two reports of Smith's course together with the 'Early Draft' of part of The Wealth of Nations. Indianapolis, Liberty Fund

Speer SA (2012) Hypothetical questions: a comparative analysis and implications for "Applied" vs. "Basic" conversation analysis. Res Lang Soc Interact 45(4):352-374. https://doi.org/10.1080/08351813.2012.724987

TEGoVA (The European Group of Valuers' Associations). 2016. European Valuation Standards 2016. TEGoVA. Retrieved from https://www.tegova.org. Accessed 4 Sept 2018.

Thapar R (2002) The Penguin History of Early India: From the Origins to AD 1300. Penguin, London von Wieser F (1889/1893) Natural value. In: Smart W (ed) Macmillan, London. http://oll.libertyfund.org/ titles/1685. Accessed 29 Aug 2019.

Publisher's Note Springer Nature remains neutral with regard to jurisdictional claims in published maps and institutional affiliations. 